\title{
DIAGNOSTIC CRITERIA FOR UNDIFFERENTIATED CONNECTIVE TISSUE DYSPLASIA IN PATIENTS WITH ARTERIAL HYPERTENSION
}

\author{
○Ye. H. Zaremba, N. O. Rak, O. V. Zaremba, O. V. Zaremba-Fedchyshyn, \\ M. M. Virna, L. O. Odnorih
}

Danylo Halytsky Lviv National Medical University

\begin{abstract}
SUMMARY. The aim - to improve the diagnosis efficiency of patients with arterial hypertension (AH) combined with undifferentiated connective tissue dysplasia (UCTD) based on the study of clinical course, the severity of UCTD external and internal symptoms with determining the levels of IL-1, IL-6, TNF- $\alpha$, free and general blood oxyproline.

Material and Methods. The study implied examination of 90 patients (52 women and 38 men) with AH of stage 2 from first to third degrees with manifestations of UCTD, who were on inpatient treatment in the Cardiology Department of the Lviv City Communal Clinical Emergency Hospital. The mean age of patients was (61.14 \pm 2.58$)$ years. Patients were divided into 3 groups depending on the stage and degree of hypertension. Group I $(n=16)$ included patients with hypertension of the first degree, group II $(n=35)$ - with AH of the second degree, group III $(n=39)$ - with AH of the third degree. The control group consisted of 20 patients with hypertension without manifestations of CTD.

Patients underwent clinical (checkup, palpation, percussion, auscultation), laboratory (determination of IL-1, IL-6, TNF- $\alpha$, free and general oxyprolin blood levels) and instrumental studies (ECG, echocardiography, DBPM, ultrasound examination of internal organs and vessels of the lower extremities, ultrasound duplex examination of the carotid and vertebral arteries, radiological examination of the osteoarticular system), consultations of an ophthalmologist, neurologist, traumatologist and dentist.

Results. As a result of the study, in the group I of patients $(n=16)$ UCTD of slight degree of severity was revealed in $13(81 \%)$, of medium degree - in $3(19 \%)$ persons. In the group II of patients $(n=35)$, UCTD of moderate severity was found in $30(86 \%)$, severe - in 5 patients (14\%). In the group III of patients ( $n=39)$, UCTD of moderate severity was found in 32 patients ( $82 \%)$, severe - in 7 (18\%). In the study of the level of TNF- $\alpha$, an increase compared to the control group was detected, particularly, in the group I of patients its level exceeded in 37.4 times, in the group II - in 39.6 times, in the group III - in 46.2 times $(p<0.001)$. IL-1 $\beta$ increased by 2.6 -fold $(p<0.05)$ in the group I of patients compared to the control group, 3.1-fold ( $p<0.01)$ - in the group II, and by 3.7-fold, that was the foremost $(p<0.001)$, in patients of the group III. In turn, IL- 6 in the group I of patients exceeded the indicators of the control group by 4.3 times ( $<<0.001)$, in the group II 4.8 times $(p<0.001)$, in the group III -5.7 times $(p<0.001)$. The study of the level of free oxyproline revealed its increase in comparison with the control group, namely in the group I of patients exceeded in 6.12 times, in the group II - in 6.81 times, in the group III - by 7.56 times $(p<0.01)$. The study of the general of bound oxyproline revealed its increase in comparison with the control group, namely in the group I of patients exceeded by 6.98 times, in the group II - by 7.79 times, in the group III - by 9.42 times $(p<0.01)$, which indicates an increase in fibrillogenesis and more pronounced destructive and inflammatory processes in connective tissue.

Conclusions. Patients with AH of the stage 2 from first to third degrees with manifestations of UCTD have increased levels of IL-1, IL- 6 and TNF- $\alpha$, which are not only sensitive markers of inflammation, but also play an important role in the pathogenesis and progression of vascular lesions, occurrence and destabilization of atherosclerotic plaques and thrombotic vessels occlusion. The determination of blood oxyprolin in patients with hypertension combined with UCTD confirms the presence of CTD, namely the decay of collagen is more pronounced in patients with severe dysplasia.

KEY WORDS: hypertension; undifferentiated connective tissue dysplasia; research methods (determination of IL-1, IL-6, TNF- $\alpha$, free and general blood oxyproline levels).
\end{abstract}

Introduction. $\mathrm{AH}$ in patients with UCTD is observed much earlier than essential $\mathrm{AH}$, namely in 8-9 years in boys and 10-12 years - in girls, which further complicates the prognosis [1, 2]. Increased blood pressure (BP) in patients with UCTD - an independent form of symptomatic hypertension, which occurs against the background of primary lesions in connective tissue dysplasia (CTD) of all target organs, thus, has its own peculiarities. Factors determining $\mathrm{AH}$ manifestation in UCTD: a family history of $\mathrm{AH}$, which is documented in $83.5 \%$ of patients with CTD with a clear predominance on maternal line (60\%), neuroinfection, trauma of the skull, kidney, spine (transferred from the first years of life), spinal pathology (scolio- sis, osteochondropathy, juvenile osteochondrosis, etc.) $[3,4,5,6]$.

The course of hypertension is accompanied by the natural occurrence of the cardiovascular system (CVS) morpho-functional changes and immunometabolic disorders. The cytokine level of immune regulation, as a source of inflammatory mediators, plays a particularly important role in the development and progression of hypertension [7, 8]. Cytokines regulate the development of local protective responses in tissues involving different types of blood cells, endothelium, connective tissue and epithelium. The role of cell growth factors and cytokines (IL-1 $\beta$, IL-4, IL-6, TNF- $\alpha$ and TNF- $\beta$ ), which take part in the develop- 
Огляди літератури, оригінальні дослідження, погляд на проблему, випадок з практики, короткі повідомлення ment of myocardial hypertrophy, has been extensively studied in recent years $[9,10]$. Particularly important in the implementation of the inflammatory response is IL-1 $\beta$, which is produced by endothelial cells and smooth muscle cells, as well as IL-6, which induces the synthesis of proteins of the acute phase of inflammation, enhances the expression of adhesive molecules, stimulates the release of vasopressor prostaglandins and nitric oxide from endothelium. TNF- $\alpha-a$ polypeptide cytokine that performs regulatory and effector functions in the immune response and inflammation, relates to proinflammatory cytokines, performs important functions during the onset of inflammation: activates the endothelium, promotes adhesion of leukocytes to the endothelium due to the induction of expression of endothelial cells subsequent transendothelial leukocytes migration into the inflammation site, activates leukocytes (granulocytes, monocytes, lymphocytes), induces the production of cytokines that have a synergistic effect with TNF- $\alpha$, IL-1, IL-6 andinterferon- $\beta$ (IFN $\beta$ ) [11].

The clinical manifestations of CTD are based on 24 abnormalities of collagen structures, the specific weight of which in the human body is about $30 \%$, in addition, $40 \%$ is in the skin, $50 \%$ - in the skeletal tissues, $10 \%$ - in the stroma of the internal organs. In the structural composition of the myocardium, along with cardiomyocytes and other cells (65\% of which include fibroblasts, endothelial cells and smooth myocytes of the walls of the blood vessels, cells of the cardiac system, macrophages) there are of type I collagen fibers, and in a smaller amount of type III, formally forming connective tissue myocardial skeleton [3]. One of the major amino acids of collagen that reflects its catabolism is oxyproline. About $20 \%$ of oxyproline-containing peptides released from collagen molecules are excreted in the urine, and $80 \%$ are metabolized in the liver. Almost $90 \%$ of urinary oxyproline is a component of small molecular weight peptides, and about $9 \%$ - of large (mainly fragments of $\mathrm{N}$-terminal procollagen type I propeptides) [4]. The level of free oxyproline serves as a marker of collagen-related degradation processes, however, general reflecting both degradation and collagen biosynthesis processes. Biochemical assessment of oxyproline levels in biological fluids is the most accessible for practical application: blood, urine, gastric juice and saliva. Increased amount of free oxyproline in the blood and urine and decreased level of bound can indicate impaired collagen synthesis and correlate with the severity of the pathological process. The main biochemical markers of CTD which should be considered, are the levels of oxyproline and glycosaminoglycans in the urine, as well as lysine, proline, oxyproline in serum as they have the highest diagnostic value.

The aim of the study - to improve the diagnosis effectiveness of the patients with hypertension combined with UCTD based on the study of clinical course, the severity of external and internal UCTD symptoms with determining the levels of IL-1, IL-6, TNF- $\alpha$, free and general blood oxyproline.

Material and Methods. The study implied examination of 90 patients (52 women and 38 men) with $\mathrm{AH}$ of the stage 2 from first and third degrees with manifestations of UCTD, who were on inpatient treatment in the Cardiology Department of the Lviv City Communal Clinical Emergency Hospital. The mean age of patients was $(61.14 \pm 2.58)$ years. Patients were divided into 3 groups depending on the stage and degree of hypertension. Group I $(n=16)$ included patients with hypertension of the first degree, group II $(n=35)$ - with $\mathrm{AH}$ of the second degree, group III $(n=39)$ - with $\mathrm{AH}$ of the third degree. The control group consisted of 20 patients with hypertension without manifestations of CTD.

Meeting of the Ethics Committee of the Danylo Halytsky Lviv National Medical University of February 26, 2018 (excerpt from protocol No. 2) gave a positive conclusion for the examination of the observance of ethical and moral principles while performing the dissertation on the topic: "Features of clinical course of clinical course hypertension associated with connective tissue dysplasia".

Patients underwent clinical (checkup, palpation, percussion, auscultation), laboratory (determination of IL-1, IL-6, TNF- $\alpha$, free and general oxyproline blood levels) and instrumental (ECG, echocardiography, DBPM, ultrasound examination of internal organs and vessels of the lower extremities, ultrasound duplex examination of the carotid and vertebral arteries, radiological examination of the osteoarticular system) studies, consultations of an ophthalmologist, neurologist, traumatologist and dentist.

Detection of CTD symptoms was performed by the method of Kadurina Tamara Ivanovna (2010).

Statistical processing of the results was performed using Microsoft Office Excel 2007 and Statistica 10.0. The data are presented as $M \pm m$ ( $M$ is the mean, $m$ is the standard error of the mean). The reliability of the results was evaluated using the Student's t-test. The difference in indicators was considered significant with $p<0.05$.

Results and Discussion. As a result of the study, in the group I of patients $(n=16)$ UCTD of slight degree of severity was revealed in 13 (81\%) persons, of medium degree - in 3 (19\%). In the group II of patients ( $n=35)$, UCTD of moderate severity was found in 30 (86 \%), severe - in 5 patients (14\%). In the group III of patients ( $n=39)$, UCTD of moderate severity was observed in 32 patients (82\%), severe in 7 patients (18\%). 
Огляди літератури, оригінальні дослідження, погляд на проблему, випадок з практики, короткі повідомлення

In the detection of external phenotypic signs in patients with hypertension, the most common manifestations of UCTD were skin striae, which accounted for $60 \%$ in the group I, $72 \%$ for the group II, $80 \%$ of patients in the group III, hypermobility of the joints of slight grade in the group I- in $25 \%$, in the group II - in $50 \%$, in the group III of patients - in $70 \%$ of patients. Spinal pathology in the form of mild scoliosis was observed in all three groups of patients. The other most common external signs of UCTD were: flatfoot present in the group I- $60 \%$, the group II $-78 \%$, the group IIIin $81.8 \%$ of patients. The appearance of patients with hypertension was supplemented by the stigma of disembriogenesis, among which macrodactyly of the first toe in the group I-70 \% of patients, the group II$83.2 \%$, the group III - in $90 \%$ of patients.

Among the interior features of UCTD in patients with hypertension often abnormal chords in the ventricles of the heart, which in group I - in $45.45 \%$, in $\mathrm{II}$ - in $55 \%$ and in group $\mathrm{III}$ - in $60 \%$ were observed, that points inferiority of connective tissue of the heart. Pathology of the eye in the form of retinal angiopathy was found in the group I- in $60 \%$, in the group II - in $85 \%$, in the group III - 90 patients, anomalies of the gall bladder (inflections, sections) in the group I of patients $-40 \%$, group II - $55 \%$, group III - in $60 \%$ of patients. Congenital malformation of cerebral vessels was observed in I - $60 \%, \mathrm{II}-85 \%$ and III $-90.9 \%$ of patients.

In patients with $\mathrm{AH}$ of the second stage from first to third degrees with UCTD, there were signs of a systemic inflammatory response, which were manifested by increased levels of proinflammatory cytokines in the blood. In the study of the level of TNF- $\alpha$, the increase compared to the control group was observed, namely in the group I of patients exceeded in 37.4 times, in the group II - by 39.6 times, in the group III - in 46.2 times $(p<0.001)$. IL-1 $\beta$ increased by 2.6-fold $(p<0.05)$ in the group I of patients, compared to 3.1 times $(p<0.01)$ - in the group II, and by 3.7 times in the group III, what was foremost in comparison with the control group $(p<0.001)$ of patients. In turn, IL- 6 in the group I of patients exceeded the indicators of the control group by 4.3 times $(p<0.001)$, in the group II -4.8 times $(p<0.001)$, in the group III 5.7 times $(p<0.001)$ (Table I).

Table I. Indicators of nonspecific immune response factors in patients with hypertension combined with undifferentiated connective tissue dysplasia

\begin{tabular}{|l|c|c|c|c|}
\hline \multicolumn{1}{|c|}{ Indicators } & $\begin{array}{c}\text { Control group, } \\
\mathrm{n}=20,(\mathrm{M} \pm \mathrm{m})\end{array}$ & $\begin{array}{c}\text { Group I, } \\
\mathrm{n}=16,(\mathrm{M} \pm \mathrm{m})\end{array}$ & $\begin{array}{c}\text { Group II, } \\
\mathrm{n}=35,(\mathrm{M} \pm \mathrm{m})\end{array}$ & $\begin{array}{c}\text { Group III, } \\
\mathrm{n}=39,(\mathrm{M} \pm \mathrm{m})\end{array}$ \\
\hline $\mathrm{IL}-1 \beta, \mathrm{pg} / \mathrm{ml}$ & $1.8 \pm 0.2$ & $4.77 \pm 1.13$ & $5.64 \pm 1.18 *$ & $6.66 \pm 1.23^{* *}$ \\
\hline $\mathrm{IL}-6, \mathrm{pg} / \mathrm{ml}$ & $2.05 \pm 0.37$ & $8.74 \pm 1.47 * *$ & $9.86 \pm 1.41$ & $11.59 \pm 1.38 * *$ \\
\hline $\mathrm{TNF}-\alpha, \mathrm{pg} / \mathrm{ml}$ & $0.05 \pm 0.01$ & $1.89 \pm 0.4 * *$ & $1.97 \pm 0.42$ & $2.24 \pm 0.47 * *$ \\
\hline
\end{tabular}

Note: $\#-p<0.05 ;{ }^{*}-p<0.01 ; * *-p<0.001-$ significance of difference of indicators in comparison with control group.

The study of blood oxyproline content allows us to evaluate the metabolism of fibrillar collagen connective tissue protein, which includes oxyproline. Oxyproline is one of the major amino acids of collagen, which makes it a marker that reflects catabolism of this protein. Oxyproline refers to the basic amino acid contained in collagen, the ratio of its fractions reflects the process of synthesis and decay of collagen. General oxyproline characterizes the breakdown activity associated with the activity of collagen biosynthesis as a process to compensate for its decay. According to the literature data, the normal level of free oxyproline is $(12.20 \pm 3.08) \mu \mathrm{mol} / \mathrm{l}$ and the level of general oxyproline is $(49.8 \pm 8.24) \mu \mathrm{mol} / \mathrm{l}[3]$. The study of the level of free oxyproline revealed its increase in comparison with the control group, namely in the first group of patients exceeded in 6.12 times, in the second -6.81 times, in the third group - in 7.56 times $(p<0.01)$. The study of the level of general oxyprolin revealed its increase in comparison with the control group, namely in the group I of patients exceeded in 6.98 times, in the group II - in 7.79 times, in the group $\mathrm{III}$ - in 9.42 times $(p<0.01)$, which indicates an increase in fibrillogenesis, more pronounced destructive and inflammatory processes in the connective tissue (Table II). Increased collagen formation is due to enhanced production of weak, immature collagen of type III.

Table II. Blood oxyproline in patients with hypertension combined with undifferentiated connective tissue dysplasia

\begin{tabular}{|l|c|c|c|c|}
\hline \multicolumn{1}{|c|}{ Indicators } & $\begin{array}{c}\text { Control group, } \\
\mathrm{n}=20,(\mathrm{M} \pm \mathrm{m})\end{array}$ & $\begin{array}{c}\text { Group I, } \\
\mathrm{n}=16,(\mathrm{M} \pm \mathrm{m})\end{array}$ & $\begin{array}{c}\text { Group II, } \\
\mathrm{n}=35,(\mathrm{M} \pm \mathrm{m})\end{array}$ & $\begin{array}{c}\text { Group III, } \\
\mathrm{n}=39,(\mathrm{M} \pm \mathrm{m})\end{array}$ \\
\hline Free oxyproline, $\mu \mathrm{mol} / \mathrm{l}$ & $7.58 \pm 0.62$ & $46.37 \pm 11.51$ & $51.64 \pm 6.41$ & $57.31 \pm 5.3$ \\
\hline General oxyproline, $\mu \mathrm{mol} / \mathrm{l}$ & $38.26 \pm 3.38$ & $71.67 \pm 13.71$ & $80.09 \pm 9.34$ & $96.69 \pm 7.10$ \\
\hline
\end{tabular}

Note: $p<0.01$ - the significance of the difference of indicators compared to the control group. 
Огляди літератури, оригінальні дослідження, погляд на проблему, випадок з практики, короткі повідомлення

The change in the levels of connective tissue markers depending on the degree of activity of the underlying pathology explains the high level of proinflammatory cytokines in serum (IL-1 $\beta$, IL-6, IL-8, TNF- $\beta$ ), which are pathogenetically linked to the levels of biochemical connective tissue markers and have an adaptation-compensatory nature aimed at collagen metabolism intensifying. Collagen genesis is stimulated by a number of signaling molecules, namely: platelet-derived growth factor, fibroblast growth factor, IL-1, IL-4, TNF- $\beta$ and TNF- $\alpha$. The increase in the concentration of free oxyproline reflects the degree of collagen decay, which is most pronounced on the first stages of the pathological process that occurs in connective tissue. In group III of patients with hypertension combined with UCTD, the level of free oxyproline was higher than in patients of groups II and I, which indicates a more pronounced collagen decay. An increase in the concentration of general oxyproline in biological fluids indicates the intensification of collagen metabolism observed in connective tissue destructive and inflammatory processes. The content of general oxyproline is more significantly increases when fibrillogenesis intensifies, indicating more pronounced destructive and inflammatory processes in connective tissue. According to the study, collagen decay was more pronounced in the group III of patients with UCTD combined hypertension.

\section{ЛІТЕРАТУРА}

1. Всероссийское научное общество терапевтов. Национальные рекомендации российского научного медицинского общества терапевтов по диагностике, лечению и реабилитации пациентов с дисплазиями соединительной ткани // Медицинский вестник Северного Кавказа. 2016. - № 11 (1). - С. 2-76.

2. Нечаева Г. И. Дисплазия соединительной ткани: сердечно-сосудистые изменения, современные подходы к диагностике и лечению / Г. И. Нечаева, А. И. Мартынов. - М. : ООО «Издательство «Медицинское информационное агентство», 2017. - 400 с.

3. Кадурина Т. И. Дисплазия соединительной ткани / Т. И. Кадурина, В. Н. Горбунова. - СПб. :ЭЛБИ, 2009. - 704 с.

4. Разработаны комитетом экспертов Российского кардиологического общества. Наследственные нарушения соединительной ткани в кардиологии. Диагностика и лечение. Российские рекомендации (1-й пересмотр) // Российский кардиологический журнал. 2013. - № 1. - С. 2.

5. Заремба $€$. Х. Особливості перебігу артеріальної гіпертензії поєднаної з дисплазією сполучної тканини в практиці сімейного лікаря / Є. Х. Заремба, Н. О. Рак, О. В. Заремба-Федчишин //Здоров'я суспільства. -2017.№ 3-4 (6). - С. 20-27.

6. Geister B. P. Cost-effectiveness and clinical effectiveness of catheter-based renal denervation for resistant
Prospects for further research. The aim of the study was to identify external and internal signs of CTD, through a comprehensive somatometric, clinical (examination, palpation, percussion, auscultation) examinations, laboratory, instrumental studies and consultations of specialists with the study of the impact of CTD on the clinical course of hypertension as a risk factor development of hypertension, further improving the diagnosis and providing practical advice on this category of people.

Conclusions. 1. In patients with $\mathrm{AH}$ of the second stage from first to third degrees with manifestations of UCTD there is an increase in levels of IL-1, IL-6 and TNF- $\alpha$, which are not only the sensitive markers of inflammation, but also play an important role in the pathogenesis and progression of vascular lesions, occurrence and destabilization of atherosclerotic plaques and vessels thrombotic occlusion.

2. Determination of blood oxyproline in patients with the second stage hypertension of first - third degrees confirms the presence of CTD, indicates the collagen decay, which is more pronounced in patients with severe dysplasia.

3. The study of UCTD in patients with hypertension opens a new approach in the treatment of hypertension, enables an individual complex of balanced nutrition measures applying and the use of various biocorrectors aimed at strengthening the connective tissue, preventing the development and progression of the disease.

hypertension / B. P. Geister, B. M. Egan, J. T. Cohen // J. American College Cardiologi. - 2012. - No. 60 (14). P. 1550-1551.

7. Дисплазия соединительной ткани в практике врачей первичного звена здравоохранения : руководство для врачей / В. М. Яковлев, Г. И. Нечаева, А. И. Мартынов, И. А. Викторова. - М. : КСТ Интерфорум, 2016. - 520 с.

8. Зарем6а $Є$. Х. Возрастные различия проявлений недифференцированной дисплазии соединительной ткани у пациентов с артериальной гипертензией: прогноз / Є. Х. Заремба, Н. О. Рак, О. М. Шевчун-Пудлик //Лечебное дело. - 2017. - № 5 (57). - С. 26-28.

9. Скляров $€$. Я. Рівень інтерлейкіну- 6 у пацієнтів 3 есенційною гіпертензією у поєднанні з ожирінням при призначенні телмісартану або олмесартану в комплексній терапії з аторвастатином / Є. Я. Скляров, О. М. Бочар // Буковинський медичний вісник. - 2016. - № 2. C. $162-165$.

10. Стаднік С. М. Роль системного запалення у морфогенезі ураження артеріальної системи / С. М. Стаднік, В. А. Лафаренко, В. А. Пилипюк // Ліки України. - 2016. № 3. - C. 11-15.

11. Цитокіновий профіль в динаміці лікування артеріальної гіпертензії / П. Г. Кравчун, О. М. Шелест, Ю. О. Ковальова, Б.О. Шелест // Артериальная гипертензия. 2014. - № 2. - С. 152-155. 
Огляди літератури, оригінальні дослідження, погляд на проблему, випадок з практики, короткі повідомлення REFERENCES

1. (2016). Vserossiyskoye nauchnoye obshchestvo terapevtov. Natsionalnyye rekomendatsii rossiyskogo nauchnogo meditsinskogo obshchestva terapevtov po diagnostike, lecheniyu i reabilitatsii patsiyentov s displaziyami soyedinitelnoy tkani [National recommendations of the Russian scientific medical society of therapists for the diagnosis, treatment and rehabilitation of patients with connective tissue dysplasia]. Medical Journal of the North Caucasus, 11 (1), 2-76 [in Russian].

2. Nechaeva, G.I., \& Martynov, A.I. (2017). Displaziya soyedinitelnoy tkani: serdechno-sosudistyye izmeneniya, sovremennyye podkhody k diagnostike i lecheniyu [Dysplasia of connective tissue: cardiovascular changes, modern approaches to diagnosis and treatment]. Moscow: Publishing House Medical Information Agency [in Russian].

3. Kadurina, T.I., \& Gorbunova, V.N. (2009). Displaziya soyedinitelnoy tkani [Dysplasia of connective tissue]. SaintPetersburg: ALBI [in Russian].

4. (2013). Razrabotany komitetom ekspertov Rossiyskogo kardiologicheskogo obshchestva. Nasledstvennyye narusheniya soyedinitelnoy tkani $v$ kardiologii. Diagnostika i lecheniye. Rossiyskiye rekomendatsii (1-y peresmotr) [Hereditary connective tissue disorders in cardiology. Diagnosis and treatment. Russian Recommendations (1st revision)]. Russkiy kardiol. Zhirn. - Russian Cardiology Journal, 1, 2 [in Russian].

5. Zaremba, Ye.H., Rak, N.O., \& Zaremba-Fedchishin, O.V. (2017). Osoblyvosti perebihu arterialnoi hipertenzii poiednanoi z dysplaziieiu spoluchnoi tkanyny v praktytsi simeinoho likaria [Features of the course of arterial hypertension combined with connective tissue dysplasia in the practice of a family doctor]. Hromadske zdorovia - Public Health, 3-4 (6), 20-27 [in Ukrainian].

6. Geister, B.P., Egan, B.M., \& Cohen, J.T. (2012). Costeffectiveness and clinical effectiveness of catheter-based renal denervation for resistant hypertension. J. American College Cardiologists., 60 (14), 1550-1551.

7. Yakovlev, V.M., Nechaeva, G.I., Martynov, A.I., \& Viktorova, I.A. (2016.) Displaziya soyedinitelnoy tkani v praktike vrachey pervichnogo zvena zdravookhraneniya [Dysplasia of connective tissue in the practice of primary care physicians]. Moscow: KST Interforum [in Russian].

8. Zaremba, Ye.H., Rak, N.O., \& Shevchun-Pudlik, O.M. (2017). Vozrastnyye razlichiya proyavleniy nedifferentsirovannoy displazii soyedinitelnoy tkani u patsiyentov s arterialnoy gipertenziyey: prognoz [Age differences in manifestations of undifferentiated connective tissue dysplasia in patients with hypertension: a prognosis]. Med. Delo - Medical Business, 5 (57), 26-28 [in Russian].

9. Sklyarov, E.Y., \& Bochar, O.M. (2016). Riven interleykinu-6 u patsiientiv z esentsiinoiu hipertenziieiu u poiednanni z ozhyrinniam pry pryznachenni telmisartanu abo olmesartanu v kompleksnii terapii z atorvastatynom [The level of interleukin-6 in patients with essential hypertension in combination with obesity when given telmisartan or olmesartan in complex therapy with atorvastatin]. Bukovyn. med. Visn. - Bukovyna Medical Bulletin, 2, 162-165 [in Ukrainian].

10. Stadnik, S.M., Lafarenko, V.A., \& Pylypiuk, V.A. (2016). Rol systemnoho zapalennia u morfohenezi urazhennia arterialnoi systemy [The role of systemic inflammation in the morphogenesis of lesions of the arterial system]. Liky Ukrainy-Medicines of Ukraine, 3, 11-15 [in Ukrainian].

11. Kravchun, P.G., Shelest, O.M., Kovaleva, Yu.O., \& Shelest, B.A. (2014). Tsytokinovyi profil v dynamitsi likuvannia arterialnoi hipertenzii [Cytokine profile in the dynamics of treatment of hypertension]. Hipertenziia - Hypertension, 2, 152-155 [in Ukrainian].

\title{
ДІАГНОСТИЧНІ КРИТЕРІЇ НЕДИФЕРЕНЦІЙОВАНОЇ ДИСПЛАЗІЇ СПОЛУЧНОЇ ТКАНИНИ У ХВОРИХ ІЗ АРТЕРІАЛЬНОЮ ГІПЕРТЕНЗІЕЮ
} ๑૯. Х. Заремба, Н. О. Рак, О. В. Заремба, О. В. Заремба-Федчишин, М. М. Вірна, Л. О. Одноріг

\author{
Львівський національний медичний університет імені Данила Галицького
}

РЕзЮМЕ. Мета - покращити ефективність діагностики хворих на артеріальну гіпертензію (АГ), поєднану 3 недиференційованою дисплазією сполучної тканини (НДСТ), на основі вивчення клінічного перебігу, вираженості зовнішніх і внутрішніх симптомів НДСТ із визначенням рівнів ІЛ-1, ІЛ-6, ФНП- $\alpha$, вільного та загального оксипроліну крові.

Матеріал і методи. Проведено обстеження 90 хворих (52 жінок та 38 чоловіків) з АГ ІІ стадії 1-3 ступенів 3 проявами НДСТ, які перебували на стаціонарному лікуванні в кардіологічному відділенні Комунального некомерційного підприємства Клінічної лікарні швидкої медичної допомоги м. Львова. Середній вік хворих становив $(61,14 \pm 2,58)$ років. Пацієнти були поділені на 3 групи залежно від стадії та ступеня АГ. До першої групи (n=16) увійшли хворі з АГ 1 ступеня, до другої ( $n=35)$ - з АГ 2 ступеня та до третьої ( $n=39)$ - з АГ 3 ступеня. Контрольну групу склали 20 хворих з АГ без проявів ДСТ.

Хворим проведено клінічні (огляд, пальпація, перкусія, аускультація), лабораторні (визначення рівнів ІЛ-1, ІЛ-6, ФНП- $\alpha$, вільного та загального оксипроліну крові), інструментальні дослідження (ЕКГ, ехоКГ, ДМАТ, УЗД внутрішніх органів та судин нижніх кінцівок, Уз дуплексне обстеження сонних і хребтових артерій, рентгенологічне дослідження кістково-суглобової системи), консультації офтальмолога, невропатолога, травматолога, стоматолога.

Результати. В результаті проведеного дослідження в обстежених I групи хворих (n=16) НДСТ легкого ступеня виявлено в 13 (81\%), середнього ступеня - в 3 осіб (19\%). У ІІ групі хворих (n=35) НДСТ середнього ступеня тяжкості виявлено в 30 (86 \%), тяжкого ступеня - в 5 пацієнтів (14\%). У III групі хворих (n=39) НДСТ середнього ступеня тяжкості виявлено в 32 пацієнтів (82 \%), тяжкого ступеня - в 7 пацієнтів (18 \%). При дослідженні рівня ФНП- $\alpha$ ви- 
Огляди літератури, оригінальні дослідження, погляд на проблему, випадок з практики, короткі повідомлення явлено його підвищення, порівняно з групою контролю, а саме у I групі хворих перевищував в 37,4 раза, у II - в 39,6 раза, у III групі - в 46,2 раза (р<0,001). ІЛ-1 $\beta$ у порівнянні з показниками контрольної групи підвищився в $2,6$ раза $(p<0,05)$ у I групі хворих, у 3,1 раза $(p<0,01)$ у II групі та найбільше, у 3,7 раза ( $<<0,001)$, у III групі хворих. IЛ-6 у I групі хворих перевищив показники контрольної групи в 4,3 раза (p<0,001), у II групі - в 4,8 раза (p<0,001), у III групі - в 5,7 раза (p<0,001). При дослідженні рівня вільного оксипроліну виявлено його підвищення, порівняно з групою контролю, а саме, у I групі хворих у 6,12 раза, у II - 6,81 раза, у III групі - в 7,56 раза (р<0,01). При дослідженні рівня загального оксипроліну виявлено його підвищення, порівняно з групою контролю, а саме у I групі хворих в 6,98 раза, у II - в 7,79 раза, у III групі - в 9,42 раза (р<0,01), що свідчить про підвищення фібриногенезу, більш виражені деструктивні й запальні процеси в сполучній тканині.

Висновки. У хворих на АГ ІІ стадії 1-3 ступенів з проявами НДСТ виявлено підвищення рівнів ІЛ-1, ІЛ-6 і ФНП- $\alpha$, які $\epsilon$ не лише чутливими маркерами запалення, а й відіграють важливу роль у патогенезі та прогресуванні процесів судинного ураження, виникненні та дестабілізації атеросклеротичних бляшок і тромботичної оклюзії судин. Визначення оксипроліну крові в хворих на АГ, поєднану з НДСТ, підтверджує наявність ДСТ, а саме розпад колагену більш виражений у хворих з тяжким ступенем дисплазії.

КлючОВІ СлОВА: артеріальна гіпертензія; недиференційована дисплазія сполучної тканини; методи дослідження (визначення рівнів ІЛ-1, ІЛ-6, ФНП- $\alpha$, вільного та загального оксипроліну крові).

\title{
ДИАГНОСТИЧЕСКИЕ КРИТЕРИИ НЕДИФФЕРЕНЦИРОВАННОЙ ДИСПЛАЗИИ СОЕДИНИТЕЛЬНОЙ ТКАНИ У БОЛЬНЫХ АРТЕРИАЛЬНОЙ ГИПЕРТЕНЗИЕЙ
}

\author{
๑Е. Ф. Заремба, Н. О. Рак, О. В. Заремба, О. В. Заремба-Федчишин, \\ М. М. Вирна, Л. О. Однориг

\section{Львовский национальный медицинский университет имени Данила Галицкого}

РЕЗЮМЕ. Цель - повысить эффективность диагностики больных артериальной гипертензией (АГ), сочетанной с недифференцированной дисплазией соединительной ткани (НДСТ), на основе изучения клинического течения, выраженности внешних и внутренних симптомов НДСТ с определением уровней ИЛ-1, ИЛ-6, ФНО- $\alpha$, свободного и общего оксипролина крови.

Материал и методы. Проведено обследование 90 больных (52 женщин и 38 мужчин) АГІІ стадии 1-3 степеней с проявлениями НДСТ, находившихся на стационарном лечении в кардиологическом отделении Коммунального некоммерческого предприятия Клинической больницы скорой медицинской помощи г. Львов. Средний возраст больных составил $(61,14 \pm 2,58)$ года. Пациенты были поделены на 3 группы в зависимости от стадии и степени АГ. В I группу ( $n=16)$ вошли больные АГ 1 степени, во II ( $n=35)$ - АГ 2 степени, В III (n=39) - АГ 3 степени. Контрольную группу составили 20 больных АГ без проявлений ДСТ.

Больным проведены клинические (осмотр, пальпация, перкуссия, аускультация), лабораторные (определение уровней ИЛ-1, ИЛ-6, ФНО- $\alpha$, свободного и общего оксипролина крови), инструментальные исследования (ЭКГ, ЭхоКГ, СМАД, УЗИ внутренних органов и сосудов нижних конечностей, УЗ дуплексное обследование сонных и позвоночных артерий, рентгенологическое исследование костно-суставной системы), консультации офтальмолога, невропатолога, травматолога, стоматолога.

Результаты. В результате проведенного исследования в I группе больных ( $n=16)$ НДСТ легкой степени тяжести обнаружена у 13 (81 \%), средней степени - у 3 человек (19\%). Во II группе больных (n=35) НДСТ средней степени тяжести виявлена у 30 (86\%), тяжелой степени - у 5 пациентов (14\%). В III группе больных (n=39) НДСТ средней степени тяжести виявлена у 32 пациентов (82 \%), тяжелой степени -у 7 пациентов (18\%). При исследовании уровня ФНО- $\alpha$ выявлено его повышение, по сравнению с группой контроля, а именно, в I группе больных - в 37,4 раза, во второй - в 39,6 раза, в III группе - в 46,2 раза ( $<<0,001)$. ИЛ-1 $\beta$, по сравнению с показателями контрольной группы, повысился в 2,6 раза $(p<0,05)$ в I группе больных, в 3,1 раза $(p<0,01)$ - во II группе, и в 3,7 раза $(p<0,001)$ в III группе больных. ИЛ-6 в I группе больных превысил показатели контрольной группы в 4,3 раза ( $<<0,001)$, во II группе - в 4,8 раза ( $<<0,001)$, в III группе - в 5,7 раза (р<0,001). При исследовании уровня свободного оксипролина обнаружено его повышение, по сравнению с группой контроля, а именно, в I группе больных в 6,12 раза, во II - 6,81 раза, в III группе - в 7,56 раза $(p<0,01)$. При исследовании уровня общего оксипролина обнаружено его повышение, по сравнению с группой контроля, а именно, в I группе больных - в 6,98 раза, во II - в 7,79 раза, в III группе в 9,42 раза ( $<<0,01)$, что свидетельствует о повышении фибриллогенеза, более выраженных деструктивных и воспалительных процессах в соединительной ткани.

Выводы. У больных АГ ІІ стадии 1-3 степеней с проявлениями НДСТ отмечается повышение уровней ИЛ-1, ИЛ- 6 и ФНО- $\alpha$, что является не только чувствительным маркером воспаления, но и играет важную роль в патогенезе и прогрессировании процессов сосудистого поражения, возникновении и дестабилизации атеросклеротических бляшек и тромботической окклюзии сосудов. Определение оксипролина крови у больных АГ, сочетанной с НДСТ, подтверждает наличие ДСТ, а именно, распад коллагена более выражен у больных с тяжелой степенью дисплазии.

КЛЮЧЕВЫЕ СЛОВА: артериальная гипертензия; недифференцированная дисплазия соединительной ткани; методы исследования (определение уровней ИЛ-1, ИЛ-6, ФНО- $\alpha$, свободного и общего оксипролина крови). 